\section{Risks of Abortion}

SIR,-May I agree with and commend the views put forward by $\mathrm{Mr}$. John Frampton (4 May, p. 298)?

It was the risks attendant upon the termination of pregnancy-increased when carried out in relatively unskilled hands-that concerned me in my letter (28 January 1967, p. 237). The fact that the actual operation may lawfully be performed by doctors without specialized knowledge of the female pelvic organs thus represents a potential menace to the women involved.

Mr. Frampton has pointed out some of the technical operative risks. Trained obstetricians know that the operation of uterine evacuation calls for that knowledgeable tactile sense combined with controlled speed and clinical understanding-particularly when the pregnancy has exceeded the ninth week, and especially in a sick patient-which can only be acquired by training, experience, and continuing obstetric practice. The registrar who is assuming operative responsibility is carefully trained and supervised, and perhaps most consultants would agree that this operation, rare enough hitherto, should be undertaken only by those who have acquired this degree of experience.

Although the Royal College of Obstetricians and Gynaecologists considers that most cases will be referred to N.H.S. hospitals and will come under the care of consultant gynaecologists, it is nevertheless probable that some will be admitted to "a place approved for the purpose by the Ministry of Health or the Secretary of State," and additionally may not come under the care of a trained and experienced obstetrician. Therein to my mind lies a danger to these women, as the numbers seeking abortion continues to increase and as hospital beds become so severely taxed as to necessitate delay in admission. The difference between the risks of the operation in the early weeks and in the weeks between the ninth and the fourteenth is considerable, and after this point an abdominal approach must be considered. The factor of time, therefore, is against the patient in this respect, and this factor, in my view, is likely to complicate the issue to an increasing extent as time goes on.

For these reasons, in my earlier letter I feared the possibility of panic measures leading to unethical surgery in inadequate surroundings (apart from authorized units) and stressed the need for the hospital consultant to be directly concerned in all cases. In this connexion the letter by $\mathrm{Mr}$. Wilfrid Mills (30 December 1967, p. 802) points out the already existing difficulties facing the hospital consultants. These I feel could be mitigated by the recognition of responsibility for assessment, references, and even the operative treatment being delegated to the chief assistant or trained registrar. This would conform with the decision of the R.C.O.G. and B.M.A. that "it be made obligatory for the termination to be carried out by or under the supervision of a consultant."

I emphasize the risks of induced termination of pregnancy, because, as $\mathbf{M r}$. Frampton says, hardly a word has been written on this aspect of the problem during the whole period of discussion of this Bill. He mention some of the immediate risks. To these could be added the long-term risks consequent upon unskilled or handicapped treatment (retained products, chronic pelvic infection, functional disorders, etc.) which come under the category of chronic pelvic disease and which have a permanent effect upon the physical and mental health of women.

I trust that the necessary thought and study will be given to this aspect by all in authority. It certainly has fascinated as well as terrified me that a Bill with such farreaching influence upon the future health of young women can come into law without its inherent risks to them being thoroughly appreciated through adequate publicized discussion. This at least might have enabled the public to understand that- to put it bluntly-there is more to it than just " giving a woman an abortion."-I am, etc.,

Manchester 3.

K. VERnon BaIley.

\section{Negligence and Doctors}

SIR,-It is surely the essential privilege of the professions that their standards are set from within and not imposed from without. For this reason a professional man has been able to resist an allegation of negligence by showing through the evidence of his fellows that he acted in accordance with an accepted practice, and this despite proof that an equally accepted practice of which he knew or should have known would have avoided the injury on which the claim against him is founded. The courts have propounded, and indeed defended, this doctrine and the professions have flourished under their protection.

It would, however, appear from the report in The Times and your leader (18 May, p. 381 ) on the case of Hucks $v$. Cole and Another that a general-practitioner obstetrician has been convicted of negligence despite the evidence of a consultant obstetrician and two other general-practitioner obstetricians that Dr. Cole had done what they themselves might or would have done in the same circumstances. The report does not suggest that the evidence of these obstetricians was either prejudiced, discredited, or even formally rejected.

The evidence of the plaintiff seems to have come from a different level of practice altogether, and in particular the point on which the defence foundered appears to have been the evidence of a consultant bacteriologist. One would have expected that the plaintiff might have called at least one general practitioner to affirm that the view of a consultant bacteriologist of a London medical school was known to and shared by the average general practitioner in the less sophisticated medical atmosphere of rural Somerset.

As you say, no substantial departure from the accepted law has been made, but as a general practitioner in law as opposed to medicine I also find myself puzzled as to the advice I should give to the hospital authorities I serve on the evidence necessary to defend a charge of medical negligence when the principle stated in the first paragraph of this letter is so clearly enunciated in a judgement which, prima facie, appears to contradict it altogether.-I am, etc.,

\section{P. W. H. Revington,} Legal Adviser, Manchester 8 Manchester Regional Hospital Board.

\section{Trimethoprim}

SIR,-The excellent review of the bacteriology of trimethoprim by Darrell, Garrod, and Waterworth ${ }^{1}$ no doubt prompted your leading article (18 May, p. 380) as a summary for your readers with clinical interests. You succeeded admirably except in one small but important detail. The efficacy of trimethoprim and sulphamethoxazole was extended to Pseudomonas aeruginosa, but Darrell et al. actually wrote that "the synergic effects on Ps. aeruginosa is presumably only of academic interest, since high concentrations of both drugs are required." This laboratory confirms that synergy only occurs at impracticable concentrations of the drug against Pseudomonas. Out of 384 strains of 27 bacterial species freshly isolated here only the 10 strains of Ps. aeruginosa showed no enhanced susceptibility. ${ }^{2}$ In a more general report of the properties of trimethoprim Bushby and Hitchings ${ }^{3}$ also showed that Mycobacterium tuberculosis and Clostridium welchii were similarly resistant. I would not therefore recommend treatment of infections due to Pseudomonas with trimethoprim and sulphamethoxazole. Eradication of Pseudomonas has so far been reported only for patients who were also infected with other organisms. Possibly in such cases Ps. aeruginosa has not been the important pathogen, or the antibacterial treatment has allowed the natural defences to concentrate successfully on a single pathogen,

The cause of the resistance of Pseudomonas to trimethoprim is known and has important practical implications. My colleague, J. J. Burchall, showed that trimethoprim binds just as firmly to the enzyme dihydrofolate reductase from Pseudomonas as it does to the enzyme of sensitive bacteria, but enters the intact Pseudomonas much less readily than it does other intact bacteria. Indeed, penetration can be improved without damage to the anti-enzyme properties of trimethoprim by altering the physical environment by such agents as Tweens.

I therefore expect that modifications of the molecule will provide a more useful way of penetrating the membrane of Pseudomonas without altering its fascinating property of inactivating bacterial enzyme, yet not influencing appreciably the enzyme of the human host.-I am, etc.

$$
\begin{aligned}
& \text { A. S. E. Fow LE. } \\
& \text { Beckenham, Kent. }
\end{aligned}
$$

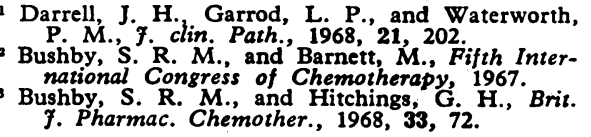

\section{E.E.G. Signs of Death}

SIR,-Your timely leading article (11 May, p. 318) draws attention to two main points that might need amplification. The first, already extensively publicized in the lay press, is the lack of a modern set of rules to help in defining the time of death when some of the patient's "vital" functions are assisted by artificial means. A working group to reconsider our present knowledge in the borderland between life and death is badly needed in this country, while modernization of the law has already evolved abroad. 